\title{
Hubungan Nilai Carcinoembryonic Antigen dengan Derajat Diferensiasi pada Karsinoma Kolorektal di RSUP Prof. Dr. R. D. Kandou Manado
}

\author{
${ }^{1}$ John Wesley, ${ }^{2}$ Toar Mambu, ${ }^{2}$ Heber Sapan, ${ }^{2}$ Winfried M. Sumanti \\ ${ }^{1}$ Program Studi Ilmu Bedah Fakultas Kedokteran Universitas Sam Ratulangi Manado \\ Indonesia \\ ${ }^{2}$ KSM Ilmu Bedah Divisi Bedah Digestif RSUP Prof. Dr. R. D. Kandou Manado \\ Email: jwesley713@gmail.com
}

\begin{abstract}
Colorectal cancer is a serious health problem in Indonesia as well as in North Sulawesi. Serum carcinoembryonic antigen (CEA) is a progmostic factor in patients with this disease. This study was aimed to obtain the correlation between the histopathological differentiation stage and serum CEA level in colorectal cancer patients at Prof. Dr. R. D. Kandou Hospital Manado. This was an analytical correlation study. Subjects were colorectal cancer patients who had preoperative serum CEA level and histopathological differentiation stage results. Data were analyzed with Anova test (variant analysis) and Spearman Rho test. The results showed that there were 58 colorectal cancer patients enrolled in this study. The patients' data were obtained from the Digestive Surgery clinic and nursery room of Prof. Dr. R. D. Kandou Hospital Manado. Of the 58 patients, 37 (63.79\%) had moderate differentiated colorectal cancer. Related to serum CEA level, 23 patients $(39.65 \%)$ had moderate differentiated colorectal cancer with serum CEA level 20-100 ng/ml. The Spearman Rho test showed that there was a positive correlation between serum CEA level and histopathoplogical differentiation stage of cancer $(\mathrm{r}=0.877$ and $P=0.001)$. Conclusion: There was a significant correlation between serum CEA level and histopathological differentiation stage of colorectal cancer. The better the differentiation stage, the higher the serum CEA level.
\end{abstract}

Keywords: carcinoembryonic antigen, colorectal cancer, differentiation stage

\begin{abstract}
Abstrak: Karsinoma kolorektal (KKR) telah menjadi masalah kesehatan yang serius di Indonesia dan Sulawesi Utara pada khususnya. Kadar carcinoembryonic antigen (CEA) merupakan salah satu faktor prognostik pada penderita KKR. Penelitian ini bertujuan untuk mengetahui hubungan antara derajat diferensiasi histopatologik dengan kadar CEA dalam serum pada pasien KKR di RSUP Prof. Dr. R. D. Kandou Manado. Jenis penelitian ini ialah analitik korelatif. Subyek penelitian ialah 58 pasien KKR yang mempunyai hasil pemeriksaan kadar CEA serum preoperasi dan pemeriksaan derajat diferensiasi histopatologik. Analisis statistik menggunakan uji Anova (analisis variansi) dan korelasi Spearman Rho. Data pasien diambil dari pasien yang datang dan kontrol di Poliklinik Bedah Digestif serta dari ruang perawatan Bedah Digestif RSUP Prof. Dr. R. D. Kandou Manado. Hasil penelitian memperlihatkan derajat diferensiasi tumor kolorektal terbanyak ialah diferensiasi sedang/moderate differentiated yaitu 37 pasien $(63,79 \%)$. Bila dihubungkan dengan nilai CEA serum, yang terbanyak ditemukan ialah jenis diferensiasi sedang pada pasien dengan kadar CEA serum 20-100 ng/ml sebanyak 23 orang (39,65\%). Uji Spearman Rho memperlihatkan bahwa kadar CEA berkorelasi positif dengan derajat diferensiasi $\mathrm{KKR}(\mathrm{r}=0,877$ dan $P=$ 0,0001). Simpulan: Terdapat korelasi bermakna antara kadar CEA serum dan derajat diferensiasi kanker kolorektal. Derajat diferensiasi KKR yang baik memiliki kadar CEA yang tinggi.
\end{abstract}

Kata kunci: carcinoembryonic antigen, karsinoma kolorektal, derajat differensiasi 
Kanker kolorektal (KKR) merupakan salah satu jenis kanker yang terjadi pada mukosa kolon. Penyakit ini mempunyai angka morbiditas dan mortalitas yang tinggi dan tersebar di berbagai negara di dunia. ${ }^{1}$ Berdasarkan data World Cancer Research Fund International (WCRF) tahun 2012 kanker kolorektal menempati peringkat ketiga setelah kanker paru dan kanker payudara sebagai kanker dengan frekuensi terbanyak, dengan 1,4 juta kasus baru. ${ }^{2}$

Di Indonesia, KKR sekarang menempati urutan nomor 3 (GLOBOCAN 2012), dengan kenaikan tajam yang diakibatkan oleh perubahan diet orang Indonesia, baik sebagai konsekuensi peningkatan kemakmuran serta pergeseran ke arah cara makan orang Barat (westernisasi) yang lebih tinggi lemak serta rendah serat. ${ }^{3}$

Carcinoembryonic antigen (CEA) adalah suatu tumor marker atau penanda tumor yang penting diperiksa dalam penatalaksanaan tumor kolorektal. ${ }^{4}$ Lebih dari tiga dekade terakhir pemeriksaan CEA ini digunakan secara luas sebagai tumor marker maupun untuk mendeteksi rekurensi dini atau asimtomatik setelah dilakukan pembedahan kuratif. Penelitian ini bertujuan untuk mengetahui hubungan antara kadar CEA dan derajat diferensiasi patologi anatomi dari KKR di RSUP Prof. Dr. R. D. Kandou Manado.

\section{METODE PENELITIAN}

Jenis penelitian ini ialah analitik korelatif untuk mengetahui hubungan dari peningkatan nilai kadar CEA dan derajat keganasan (diferensiasi sel) pada pasien karsinoma kolorektal di Rumah Sakit RSUP Prof. Dr. R. D. Kandou Manado. Penelitian ini dilakukan di Sub Bagian Bedah Digestif RSUP Prof. Dr. R. D. Kandou Malalayang mulai dari Januari 2017 s/d Desember 2017 dengan jumlah sampel 58 pasien KKR.

\section{HASIL PENELITIAN}

Pada penelitian ini didapatkan 58 pasien yang terbukti KKR berdasarkan data pemeriksaan patologi anatomi yang memenuhi kriteria inklusi penelitian. Distribusi menurut karakteristik pasien dijabarkan dalam Tabel 1 s/d 4. Terdapat peningkatan insidens KKR yaitu dari 26 pasien pada tahun 2016 menjadi 32 pasien pada tahun 2017 (Tabel 1).

Tabel 1. Insidens karsinoma kolorektal tahun 2016-2017 di RSUP Prof. Dr. R. D. Kandou

\begin{tabular}{cc}
\hline Tahun & N \\
\hline 2016 & 26 \\
2017 & 32 \\
Jumlah & 58 \\
\hline
\end{tabular}

Berdasarkan lokasi karsinoma pada pasien KKR di tahun 2016-2017 didapatkan terbanyak pada rektum, disusul oleh rektosigmoid dan sigmoid (Tabel 2).

Tabel 2. Insidens karsinoma kolorektal berdasarkan lokasi karsinoma tahun 2016-2017

\begin{tabular}{ccc}
\hline Lokasi & $\mathbf{N}$ & $\mathbf{\%}$ \\
\hline Rektum & 23 & 39,65 \\
Rektosigmoid & 11 & 18,96 \\
Sigmoid & 9 & 15,55 \\
Descendens & 7 & 12,06 \\
Tranversum & 2 & 3,44 \\
Ascendens & 6 & 10,34 \\
Jumlah & 58 & $100 \%$ \\
\hline
\end{tabular}

Berdasarkan jenis kelamin didapatkan pasien berjenis kelamin laki-laki (40 orang), lebih banyak daripada perempuan (18 orang) (Tabel 3).

Tabel 3. Distribusi pasien berdasarkan jenis kelamin

\begin{tabular}{ccc}
\hline Jenis kelamin & N & \% \\
\hline Laki-laki & 40 & 68,9 \\
Perempuan & 18 & 31,1 \\
Jumlah & 58 & 100 \\
\hline
\end{tabular}

Berdasarkan usia, pasien terbanyak pada kelompok usia 50-59 tahun $(32,78 \%)$ diikuti oleh kelompok usia 40-49 tahun dan 70-79 tahun (masing-masing 17,24\%), kelompok usia 60-69 tahun (15,51\%), dan yang paling sedikit pada kelompok usia 8089 tahun $(3,44 \%)$ (Tabel 4$)$ 
Tabel 4. Distribusi pasien berdasarkan usia

\begin{tabular}{ccc}
\hline $\begin{array}{c}\text { Usia } \\
\text { (tahun ) }\end{array}$ & $\mathbf{N}$ & $\boldsymbol{\%}$ \\
\hline $20-29$ & 5 & 8,62 \\
$30-39$ & 3 & 5,17 \\
$40-49$ & 10 & 17,24 \\
$50-59$ & 19 & 32,78 \\
$60-69$ & 9 & 15,51 \\
$70-79$ & 10 & 17,24 \\
$80-89$ & 2 & 3,44 \\
Jumlah & 58 & 100 \\
\hline
\end{tabular}

Berdasarkan derajat diferensiasi tumor, distribusi pasien terbanyak pada diferensiasi tumor derajat sedang $(63,79 \%)$, diikuti oleh derajat baik $(20,69 \%)$ dan derajat buruk $(15,52 \%)$ (Tabel 5).
Perbedaan CEA menurut derajat diferensiasi (baik, sedang, buruk) diuji dengan uji Anova (analisis variansi) yang menyatakan bahwa terdapat perbedaan sangat bermakna dalam hal rerata antara CEA pada ketiga derajat diferensiasi $(P$ $<0,0001)$. Perbedaan ini terjadi antara rerata CEA pada derajat buruk dan sedang $(P=0,042)$; antara rerata CEA pada derajat buruk dan baik $(P<0,0001)$; dan antara rerata CEA pada derajat sedang dan baik $(P$ $<0,0001)$.

Hubungan kadar CEA dan derajat diferensiasi KKR diuji menggunakan Spearman's rho yang mendapatkan koefisien korelasi sebesar 0,877 dengan signifikansi 0,0001 .

Tabel 5 . Hubungan CEA dengan derajat diferensiasi KKR

\begin{tabular}{|c|c|c|c|c|c|c|c|c|c|c|}
\hline \multirow{3}{*}{$\begin{array}{c}\text { Derajat } \\
\text { diferensiasi } \\
\text { tumor }\end{array}$} & \multicolumn{8}{|c|}{ CEA } & \multirow{2}{*}{\multicolumn{2}{|c|}{ Total }} \\
\hline & \multicolumn{2}{|c|}{$<5 \mathrm{ng} / \mathrm{ml}$} & \multicolumn{2}{|c|}{$5-20 \mathrm{ng} / \mathrm{ml}$} & \multicolumn{2}{|c|}{$20-100 \mathrm{ng} / \mathrm{ml}$} & \multicolumn{2}{|c|}{$>100 \mathrm{ng} / \mathrm{ml}$} & & \\
\hline & $\mathbf{n}$ & $\%$ & $\mathbf{N}$ & $\%$ & $n$ & $\%$ & $\mathbf{N}$ & $\%$ & $\mathbf{N}$ & $\%$ \\
\hline Baik & 0 & 0,00 & 1 & 1,72 & 2 & 3,44 & 9 & 15,51 & 12 & 20,69 \\
\hline Sedang & 0 & 0,00 & 8 & 13,79 & 23 & 39,65 & 6 & 10,34 & 37 & 63,79 \\
\hline Buruk & 1 & 1,72 & 7 & 12,06 & 1 & 1,72 & 9 & 15,51 & 9 & 15,52 \\
\hline Jumlah & 1 & 1,72 & 16 & 27,57 & 26 & 44,82 & 25 & 43,10 & 58 & 100 \\
\hline
\end{tabular}

\section{BAHASAN}

Distribusi sampel berdasarkan tahun memperlihatkan pasien KKR terbanyak pada tahun 2017 yaitu 32 pasien sedangkan pada tahun 2016 sebanyak 26 pasien (Tabel 1). Pasien KKR tanpa hasil pemeriksaan CEA dan hasil CT-scan tidak memenuhi kriteria inklusi dan tidak diikutsertakan dalam penelitian. Saat ini pemeriksaan CEA lebih banyak digunakan untuk menilai rekurensi pasca operatif dan masih jarang digunakan untuk prognostik dan diagnostik preoperatif.

Insidens yang tersering sesuai lokasi karsinoma ialah di rektum $(39,65 \%)$ diikuti oleh rektosigmoid $(18,96 \%)$, kolon sigmoid $(15,55 \%)$, kolon desendens (12,06\%), kolon asendens $(10,34 \%)$, dan yang paling jarang ialah di kolon tranversum $(3,44 \%)$
(Tabel 2). Urutan lokasi KKR ini berbeda dengan di negara lain. Di Amerika berdasarkan American Cancer Society (2016) didapatkan lokasi tersering justru pada kolon sigmoid dan rektum ynng menempati urutan kedua namun penelitian Brunner et al. melaporkan pada tahun 2005 di Amerika, lokasi karsinoma kolorektal tersering ialah rektum (38\%), dikuti oleh sigmoid (29\%), sekum (15\%), kolon transversum (10\%), serta kolon asendens (5\%) dan kolon descendens $(3 \%) .5$ Penelitian oleh Siegel $^{5}$ di Amerika Serikat mendapatkan lokasi KKR yang tersering ialah di kolon distal (sigmoid) dan paling jarang di kolon proksimal (kolon asendens dan tranversum).

Pada distribusi pasien KKR berdasarkan jenis kelamin didapatkan sebanyak 40 
orang laki-laki $(68,9 \%)$ dan 18 orang perempuan $(31,1 \%)$ menderita KKR (Tabel 3). Hasil penelitian ini sejalan dengan yang dipaparkan oleh American Cancer Society tahun 2017 yang menyatakan bahwa pada hasil survei didapatkan jenis kelamin lakilaki lebih banyak menderita KKR dibandingkan perempuan dan hal ini terjadi pada semua ras/etnis di Amerika, dengan persentase 45,9:100.000 pada laki-laki dan 34,8:100.000 pada perempuan di tahun 2011-2014. Sekitar 50 studi kasus-kelola atau kohort yang mencakup 13.000 kasus menunjukkan hasil yang konsisten bahwa aktifitas fisik menekan risiko (pengurangan risiko sampai 50\%) kejadian karsinoma kolon. Hubungan ini kuat pada jenis kelamin laki-laki dan karsinoma kolon, tetapi pengaruhnya hanya sedikit pada karsinoma rektum baik pada laki-laki maupun perempuan. ${ }^{5}$

Pada penelitian ini didapatkan distribusi sampel berdasarkan usia paling banyak pada dekade keempat dan kelima. Data yang didapatkan menunjukkan KKR paling banyak terdeteksi pada rentang usia 50-59 tahun $(32,78 \%)$, diikuti rentang usia 40-49 tahun $(17,24 \%)$, usia $70-79$ tahun $(17,24 \%)$, usia 60-69 (15,51\%), usia 20-29 tahun $(8,62 \%)$, usia $30-39(5,17 \%)$, dan usia $80-89$ tahun $(3,44 \%)$ (Tabel 4). Data Kementerian Republik Indonesia (2017) dari data Globocan 2012 memaparkan insiden KKR di Indonesia ialah 12,8 per 100.000 penduduk usia dewasa, dengan mortalitas 9,5\% dari seluruh kasus kanker. ${ }^{2}$ Hasil penelitian ini tidak selaras dengan data American Cancer Soceity (2017) yang melaporkan bahwa persentase paling tinggi dari KKR pada usia di atas 70 tahun $(38,8 \%)$, disusul oleh usia 60-69 tahun $(11,7 \%)$, usia 50-59 tahun (7\%), dan usia di bawah 50 tahun $(3,5 \%)$ dari total 135.310 penderita KKR. ${ }^{6}$

Hasil penelitian ini memperlihatkan gambaran kadar CEA serum dan derajat diferensiasi KKR (Tabel 5). Derajat diferensiasi terbanyak ialah differensiasi sedang/moderate differentiated $(63,79 \%)$, sedangkan bila dihubungkan dengan nilai CEA, yang terbanyak ditemukan ialah jenis diferensiasi sedang/moderate differentiated pada pasien dengan kadar CEA 20-100 $\mathrm{ng} / \mathrm{ml}$ sebanyak 23 orang $(39,65 \%)$. Hubungan antara CEA dan derajat diferensiasi diuji dengan analisis koefisien korelasi Spearman karena data derajat diferensiasi berbentuk kategori ordinal. Hasil uji ini memperoleh nilai korelasi $r_{\mathrm{s}}=0,877$ dengan $P<0,0001$, yang menyatakan terdapat hubungan positif yang kuat dan bermakna antara CEA dan derajat diferensiasi KKR. Beberapa penelitian telah menunjukkan bahwa KKR dengan diferensiasi baik memroduksi lebih banyak CEA per gram total protein dibanding dengan spesimen yang berdiferensiasi buruk. Saito ${ }^{7}$ melaporkan bahwa adenokarsinoma berdiferensiasi baik memiliki kadar CEA tertinggi serta pewarnaan yang kuat, sedangkan adenokarsinoma berdiferensiasi buruk memiliki kadar CEA serum rendah serta pewarnaan yang lemah dengan cut-off point $5 \mathrm{ng} / \mathrm{ml}$. Pada penelitian Duffy ${ }^{8}$ didapatkan hasil rerata kadar CEA pada tumor berdiferensiasi baik, sedang, dan buruk secara respektif ialah 18,$0 ; 5,5$; dan 2,2 $\mathrm{ng} / \mathrm{ml}$. Kurangnya atau buruknya diferensiasi yang mungkin dapat menjelaskan mengapa pada beberapa pasien dengan KKR stadium lanjut tidak mengalami peningkatan kadar $\mathrm{CEA}^{7}$ Hal ini juga ditunjang oleh Polat et al. ${ }^{9}$ yang menyatakan bahwa kadar CEA serum mengalami tren peningkatan pada pasien dengan tumor berdiferensiasi baik dibandingkan pada tumor berdiferensiasi buruk. Hasil penelitian oleh $\mathrm{Li}^{10}$ menyatakan bahwa kadar CEA serum cenderung lebih meningkat pada pasien KKR berdiferensiasi baik dibanding dengan yang berdiferensiasi buruk yang menunjang hasil penelitian ini, dan juga diperkuat oleh Bhatnagar ${ }^{11}$ yang melaporkan bahwa kadar CEA jaringan ialah yang tertinggi pada adenokarsinoma berdiferensiasi baik $(5,2-37 \mu \mathrm{g} / \mathrm{gr}$ protein) dan sangat rendah pada adenokarsinoma berdiferensiasi sedang dan buruk, dan pada individu normal. Hasil penelitian oleh Raehaan ${ }^{12}$ mendapatkan bahwa rerata kadar CEA pada adenokarsinoma kolorektal berdiferensiasi baik, sedang, dan buruk 
ialah berturut-turut $120,91 \mathrm{ng} / \mathrm{ml}, \quad 42,40$ $\mathrm{ng} / \mathrm{ml}$, dan $27,51 \mathrm{ng} / \mathrm{ml}$.

\section{SIMPULAN}

Dari hasil penelitian ini dapat disimpulkan bahwa terdapat korelasi bermakna antara kadar CEA pre operatif dengan derajat diferensiasi karsinoma kolorektal.

\section{DAFTAR PUSTAKA}

1. Roche. Colorectal cancer A guide for journalists on colorectal cancer and its treatment. Available from: https: //www.roche.com/dam/jcr:8e 08ab404ae0-4c61-99dd-a139cce45edc/en/ med-colorectal-cancer.pdf. p. 1-10

2. Globocan 2012. Coloretal cancer incidence and mortality worldwide in 2012. Available from: http://globocan.iarc.fr/old/Fact Sheets/cancers/colorectal-new.asp

3. Ferlay J, Soerjomataram I, Dikshit R, Eser S, Mathers C, Rebelo $M$, et al. GLOBOCAN 2012 v1.1, Cancer incidence and mortality worldwide: IARC CancerBase No. 11 [Internet]. Lyon, France: International Agency for Research on Cancer; 2014. Available from: http://www.wcrf.org/int/cancerfacts-figures/worldwide-data

4. Brenner BM, Ota DM. Adenocarcinoma of the colon and rectum (Chapter 15). In: ACS Surgery: Principles and Practice WebMD Inc 2005. Available from: https://www.slideshare.net/medbookonl ine/acs0515-adenocarcinoma-of-thecolon-and-rectum-2005.

5. Siegel R, Desantis C, Jemal A. Colorectal cancer statistics, 2014. CA Cancer J
Clin. 2014;64(2):104-17.

6. American Cancer Society. Cancer statistics center. Colorectum. 2017. Available from: https://www.cancer.org/ research/ cancer-facts-statistics.html.

7. Saito G, Sadahiro S, Okada K, Tanaka A, Suzuki T, Kamijo A. Relation between carcinoembryonic antigen levels in colon cancer tissue and serum CEA at initial surgery and recurrence. Oncology. 2016;91(2):85-9

8. Duffy MJ. Carcinoembryonic antigen as a marker for colorectal cancer: is it clinically useful?Clinical Chemistry. 2001;47(4):624-30.

9. Polat E, Duman U, Duman M, Atici AE, Reyhan E, Dakgic T, et al. Diagnostic value of preoperative serum CEA and carbohydrate antigen 19-9 in colorectal cancer. Curr Oncol. 2014;21(1):e1-e7.

10. Li M, Li JY, Zhao AL, He JS, Zhou LX, Li YA, et al. Comparison of carcinoembryonic antigen prognostic value in serum and tumour tissue of patients with colorectal cancer. Colorectal Dis. 2009;11(3):276-81.

11. Bhatnagar J, Tewani HB, Bhatnagar M, Austin GE. Comparison of CEA in tissue and serum with grade and stage of colon cancer. 1999. US national library of medicine national institutes of health. Anticancer Res. 1999;19(3B): 2181-7.

12. Raehaan NR, Asvin N, Mansyur A. Carcinoembryonic antigen (CEA) di kanker kolorektal. Indonesian Journal of Clinical Pathology and Medical Laboratory. 2014; 20(3):192-6. 